\title{
Financialisation of schooling in Australia through private debt: a case study of Edstart
}

\author{
Anna Hogan'10
}

Received: 2 February 2021 / Accepted: 9 August 2021 / Published online: 3 September 2021

(C) The Australian Association for Research in Education, Inc. 2021

\begin{abstract}
In Australia, a range of financial services, including education bonds, high interest personal loans and credit card debt, have long been used to help families pay for the cost of schooling. However, innovative financial technology (fintech) solutions are emerging which align with the growth of a lower risk 'buy now, pay later' phenomenon. Fintechs claim to expand financial inclusion to more people, particularly when their lending activities are compared to traditional banking services. This paper focuses on Edstart, a fintech edu-business that provides low-risk lending for families managing the cost of school fees. In conducting qualitative content analysis of Edstart's website and blog, I catalogue its market-making activities and how it is leveraging logics of school choice to create a new education service market in Australia that normalises school privatisation and the payment of school fees. I end this paper with a discussion of how school choice-as a key policy reform of governments-is associated with the rollback of the welfare state and increased levels of individual financialisation. I argue that parent consumers have become increasingly invested in choosing the 'best' school for their children, and that this often increases their level of private debt.
\end{abstract}

Keywords Privatisation $\cdot$ School choice $\cdot$ Parent consumers $\cdot$ School fees $\cdot$ Venture capital $\cdot$ Edu-business $\cdot$ Fintech

Anna Hogan

ar.hogan@qut.edu.au

1 Queensland University of Technology, Brisbane, Australia 


\section{Introduction}

Australia's school fee market is valued at over $\$ 7$ billion per year ${ }^{1}$. Regardless of school type-Government, Catholic or Independent-parents are charged fees to enrol their children in schooling. Of course, government schools are typically more affordable, with an average annual fee (or voluntary contribution) of $\$ 434$, whereas Catholic schools and Independent schools charge, on average, \$2300 and \$7538, respectively (Thompson et al., 2019). At the top end of the scale, the most expensive private schools charge upwards of $\$ 30,000$ per year. Indeed, market-based research conducted by Australian Scholarships Group (2016), now known as Futurity Investment Group, argues that a family enrolling their child in the Government school system is likely to pay a total cost of $\$ 66,862$ over 13 years of schooling, and this increases to $\$ 230,381$ in the Catholic system and $\$ 468,397$ in the Independent system. While this report was published by an edu-business that provides education bonds to Australian families to save for school fees, and thus should be treated cautiously as advocacy-oriented research with particular conceptions of 'evidence', 'expertise' and 'influence' (Thompson, Savage \& Lingard, 2016), it highlights that school fees are a substantial call on a family's after-tax income (Laws \& Fielder, 2002).

The high cost of schooling in Australia is commonly discussed in news media. Countless articles explore strategies, and their pros and cons, for paying school fees. Long-term saving strategies include education bonds, managed funds, and a diversified share portfolio. These takes years of advanced planning, where for example, families decide from birth that they will enrol their child in a particular type of school, and whether this is for all years (prep-12), from middle years (4/5-12) or from secondary years (7-12). They then enter a long-term commitment to saving the required funds. Shorter-term solutions include redrawing on a mortgage, taking personal loans, using credit card debt, or asking extended family members (especially grandparents) for assistance (Bolton, 2019). These strategies more closely align with the 'buy now, pay later' phenomenon where consumers take on personal debt and potentially high interest rates. Aligned with this short-term solutionism, is the emergence of new services provided by financial technology ('fintech') businesses. Fintechs argue that their services are lower risk than traditional (high interest) bank services. They are typically lower-cost because they have reduced overheads given their services are offered through a 'virtual' marketplace of digital applications (Soriano, 2018). They offer instalment payments, where for instance, repayments are made automatically as an individual receives their salary income (Gabor \& Brooks, 2017). And, perhaps most usefully, fintechs provide customised solutions for specific financial problems (Weichert, 2017).

\footnotetext{
1 This figure is a conservative estimate based off previous research (Thompson et al., 2019), where average 'Fees, Charges and Parental Contributions' (see My School finance data) across each of Australia's three school sectors was multiplied by the number of students enrolled in each school sector. Some news media sources report this figure to be closer to \$10 billion (Wade \& Singhal, 2018).
} 
The Australian fintech startup, Edstart, offers 'fit-for-purpose' services to pay school fees. It turns up-front fee payments into weekly, fortnightly, or monthly repayments that can be spread between 12 months and 10 years. The company is backed by venture capital and is creating a novel new market in education. Rather than privatising education (e.g. running schools), or commercialising schooling (e.g. selling teaching and learning materials), this edu-business is operating explicitly for parent consumers and profiting from Australia's school choice agenda. Edstart also works as a case to show that the consumption of schooling in Australia is increasingly viewed as a private, positional good (Verger et al., 2016). It highlights how education policy reforms that have promoted competition and choice, are working to substitute private debt for the welfare state (Cooper, 2017). It also demonstrates how parents are constructed as consumers responsible for their children's success in a competitive world, and why they are motivated to take on personal debt for their school of choice.

In what follows, I first provide background on school choice in Australia, and the long-held assumption that paying more for schooling secures a 'better' education. I also track the rise of venture capital in schooling and how fintech edu-businesses are capitalising on a for-profit opportunity in helping families finance school fees. Secondly, I provide a case study of Edstart. Through qualitative content analysis of Edstart's website and blog, it is possible to catalogue its market-making activities and how it has leveraged logics of school choice to create a new education service market in Australia. I end this paper with a discussion of how school choice-as a key policy reform of governments-is associated with increased levels of financialisation and personal debt.

\section{School choice in Australia}

Much research has explored why Australia has a high percentage of private school enrolments. Generally, both Australia's colonial past (Potts, 1997) and successive Federal Government education policy agendas (Forsey et al., 2017) are cited as key reasons. In terms of providing sufficient background within the constraints of this paper, it is best to focus on the post-World War II era. Education during this time was driven by an understanding that schooling did not just stand to benefit individuals, but was important for citizenship in a democracy. The era of the 'welfare state' not only pushed a full and comprehensive public education for all, but also took some responsibility for poverty stricken Catholic schools that had been without state-aid since the late 1800s. Indeed, the Karmel report (1973) commissioned by the Whitlam Labor government, argued that a new federal funding system was required that would enable school authorities to remedy deficiencies, particularly in non-government schools that fell outside the constitutional care of state governments. "Hence, at the very height of free, compulsory and secular education, governments set in place the precedents and structures for funding privately-run, feecharging schools" (Bonnor \& Shepherd, 2016, p.14).

Since this time, federal subsidies - through general recurrent funding-have continued to grow for private schools. Yet, as Lingard (2000) observes, the 
rationale for this is less about equity, and more about expanding parental choice in schooling. This follows the growing influence-at least since the 1980s-of neoliberal ideologies and the growing influence of privatised public service provision. The rationale for choice and competition-particularly between schoolsis that it drives systemic improvements (Le Grand 2009). Yet, a plethora of research has shown that Australia's school system is highly stratified. Scholars such as Vickers (2005) and Kenway (2013), have taken issue with the private school 'advantage' and have illustrated inequities in funding arrangements that often leave public schools worse off than their private school counterparts. Yet, the 2011 Review of Funding for Schooling (the Gonski report) commissioned by the Gillard Labor government, maintained the view that federal government funding should continue for private schools:

A strength of Australia's schooling system is the diverse range of schools and schooling experiences available to students and their parents across the government and non-government sectors. Arrangements for public funding should foster this diverse provision and allow choice by parents. (Gonski et al., 2011, p.150)

While there is not enough room in this paper to provide a detailed overview of Gonski, suffice to say that despite arguing for a more equitable funding model that would support all schools on the basis of student need, the Gillard ALP government (2010-2013) failed to obtain the necessary state and territory support for the new funding arrangements proposed. Essentially, there was discord among federal and state governments about committing the funding required for the national schooling resource standard, and simultaneously, debate raged about how private schools might lose some of their state-aid, while government schools would remain underfunded (Gerrard et al., 2017). For the past decade, there has been increased public and professional awareness of, and dissatisfaction with, inequitable funding arrangements within Australia's school system. Moreover, I would argue that Gonski-and its part political failings - has acted as a constant reminder, and source of anxiety for many families about the ramifications of school choice.

While approximately one third (34.3\%) of Australia's P-12 enrolments are students in private schools (ABS, 2020), this percentage increases to over $40 \%$ when viewing enrolments for secondary schooling alone. As Di Bartolo (2005) suggests, there's a prevailing assumption amongst Australian parents that secondary schooling is more important for the 'life chances' of their children. A survey conducted by Independent Schools Australia (2017) — an advocacy group that represents the interests of the Independent school sector-found parents are influenced by a variety of factors when choosing a private school, including religious affiliation, academic outcomes, quality teaching and leadership, school facilities, content of the curriculum, and the range of extra-curricular activities on offer. More critical research, however, often focusses on the social and cultural capital afforded to families through private schooling. English (2009) argues that parents choose private schools to access a perceived 'better life' for their children. Kenway (2013) explains that students often adopt a sense of social distinction and entitlement in private schools, fuelled by "alumni nostalgia, parental ambitions and student aspirations" (p. 304). 
However, public schools are not immune from the logics of choice either. Research has shown how 'public' schools have been re-positioned as autonomous organisations competing for clients as much as they are schools educating students (Fitzgerald et al., 2018). Rowe and Lubienski (2017) investigated public school stratification, where for example, parents in Victoria are buying property within desirable school catchment areas. Other researchers have focussed on how academically selective public schools are segregating high-achieving students out of comprehensive public schools, further polarising student outcomes between selective and nonselective public schools (Ho, 2019). Often, these 'elite' or first choice public schools have much higher fees than comprehensives, charging voluntary contributions comparable to lower-cost private schools (Rowe \& Perry, 2020).

\section{Financialisation of schooling}

As Gerrard, Savage and O'Connor (2017, p. 515) observe, government schooling in Australia is framed as a "social safety net for those not in a position to access private schooling". They argue that this taken-for-granted logic is present in both policy and popular debate, in which government schooling is always positioned in deficit to private schooling. However, as Cooper (2020) suggests such logics are shaped by neoliberal ideals that tend to invoke the 'natural obligations' of family to serve as a substitute for the welfare state. Cooper (2017 p. 22) argues that the neoliberal economists of the 1960s, like Milton Friedman and Gary Becker, proposed new models of funding that would replace public with private deficit spending,

Under their influence, welfare has been transformed from a redistributive program into an immense federal apparatus for policing the private family responsibilities of the poor, while deficit spending has been steadily transferred from the state to the private family. Through policies designed to democratize credit markets and inflate asset values, these reformers have sought to revive the tradition of private family responsibility in the idiom of household debt. (Cooper, 2017, p.22)

In the context of education, private family spending has come to be considered an investment rather than an act of consumption, and education itself is understood as a form of capital or interest-bearing asset (Cooper, 2020). As Winton and Milani (2017) describe, parents are now constructed as consumers who are responsible for their children's success in a competitive world, and within this context, governments are understood as only being responsible for providing the basic requirements of education. Increasingly, education is understood to be a private, positional good (Verger et al., 2016), where investment now reflects the impact of schooling on future productivity and wages (Adnett \& Davies, 2002). Of course, there are collective individual and economic benefits of education, but as Verger et al. observe,

Just as nations strive to increase their competitive advantage in the global marketplace through improved education, families in those nations often compete for sought-after spots for their children in what are perceived as relatively 
better schools... as education becomes a positional good with social cachet connected to one's particular consumption, and not only a route to enhanced employment prospects. (p. 8)

Often these desirable spots come at a higher cost to the consumer. This means that families are turning to financial markets in demand for credit.

Financialisation is defined by Epstein (2005, p. 3) as simply "the increasing role of financial motives, financial markets, financial actors and financial institutions in the operation of domestic and international economies". But, as Finlayson (2009) argues, it also has an important individual or household dimension. In the context of dwindling state welfare, there has been an unprecedented rise in private debt as individuals are motivated to take charge of and fund their future financial needs. Such debt levels, according to Finlayson (2009), indicate that individual relationships with finance have changed, along with individual expectations and aspirations about life. Lai (2017) observes that risk and risk-taking behaviour have become normalised through individual consumption of financial products, and while many view this as the democratisation of finance to a broader public, others see it as the creation and extension of new risks with uneven impacts. For example, in education, financialisation opens up school choice to more people. Rather than relying solely on understandings of class, access to a school of choice centres on the aggregate position of growing indebtedness (Martin et al., 2008). Of course, not all families have access to the same levels of financialisation as others, but many can access a degree of financial empowerment so that they might act as rational choice agents, and enrol their children in their school of choice.

\section{Education payment plans, venture capital and fintech}

Education payment plans are not a new phenomenon in Australia. Futurity Investment Group has existed since 1974 to provide education bonds to Australian families. In fact, many insurance companies offer education bonds, or as deemed under Australian law, 'scholarship plans' to help families make regular contributions to a tax effective education fund to help offset future school fees. Importantly, money is generated by members, and invested by the holding company. However, the rise of venture capital in education is creating opportunities for new types of financial products that allow consumers to access money now and pay later.

Typically, private investors are willing to invest in education businesses due to their potential profitability and as Ball (2012) observes there are different sorts of money involved in financing education: "There is big money and small money; both multinational businesses and local entrepreneurs; multi-million-dollar investments and microloans" (p. 141). Most research dealing with venture capital in education has explored how commercial startups have had significant financial backing to 'disrupt' the traditional vision of schooling (Williamson, 2018). Often this disruption comes in the form of technological advancement. EdTech, datafication, personalised learning and Artificial Intelligence, for example, are all moves in education that have garnered huge financial backing through venture capital and philanthropy 
(Williamson, 2018; 2020). Less attention, however, has been paid to the emergence of marketplace lending in educational 'fintech' companies. Like other educational startups that are unlikely to receive a bank loan, these companies receive private equity financing through angel investments, crowdfunding, peer-to-peer lending and/or other seed funding options (Bollaert et al., 2021). Often, venture capital firms act as intermediaries, investing capital from pension funds, family offices, insurance companies, high net worth and wholesale investors into financing startups with high-growth potential (Herck Giaquinto \& Bortoluzzo, 2020).

Fintech or 'financial technology' emerged after the 2008 Global Financial Crisis. It is largely led by non-bank companies and is driven by new information technologies, including "mobile phones, cloud computing, big data analytics, artificial intelligence, and blockchain" (Soriano, 2018, p. 60). These innovations make it possible to offer financial services directly to consumers, more-or-less independently of traditional banking institutions (Gabor \& Brooks, 2017). As Brown and Piroska (2021) argue, fintech is embedded in discourses of 'innovation' and 'solutionism' and is often referred to as a vehicle for supporting broader 'financial inclusion',

$[F]$ intech is now put forward as the means to bring about a 'solution' to the inability of the poor to access and utilise capital to lift themselves through entrepreneurship. Therefore, fintech discourse depicts fintech as a kind of innovation that it capable of ameliorating, or indeed as a solution for, the socio-economic situation of a large number of customers. (p. 3)

Indeed, Gabor and Brooks (2017, p. 431) describe the rise of fintech as marking a shift from the welfare state and its "collective pooling of risk in public pensions, housing, education and labour market protection" to fostering the individual's ability to deal with contingencies and uncertainties. They argue that fintech doesn't change the material structure that generates marginality, but rather seeks to channel individual behaviour. Thus, they caution that discourses of inclusion obscure the desire of financial capital to access high return markets: "In this case, the role of the state is recast to provide 'an enabling environment' for financial capital to flow freely, while allowing the consequences of systemic risks to be transferred to consumers precariously positioned at the "bankable frontier'" (Gabor \& Brooks, 2017, p. 433). Thus, successful fintechs serve a civic purpose, while being extremely profitable. Like researchers have demonstrated in the field of education privatisation and commercialisation, successful business ventures purport to straddle the for-profit and civil sectors by creating public-facing, civic-minded companies (Ball, 2012; Hogan et al., 2016; Verger et al., 2016).

\section{Method}

The analytical component of this study involved content analysis of blogs published by Edstart. Blogs have become a popular tool for business brand building and can work to create and sustain long-term relationships with customers (Singh et al., 2008). As He and Chen (2014) argue, corporate blogs enable companies to create buzz about products and events and provide opportunities to inform consumers 
about developments. Philip (2017) observes that corporate blogs have become an essential PR tool for many businesses and are a cost-effective way to generate greater reach and timely targeted dialogue. But she also cautions that successful blogs are not filled with self-serving propaganda, rather they seek to connect with their customers through broad messages and shared interests. This means that along with brand positioning posts that are consistent with corporate missions, companies must also post about issues that are interesting and engaging to their clientele (Wei et al., 2020). Thus, when analysing a corporate blog it is important to define who the company is trying to communicate with. In the case of Edstart, it is focussed on parent consumers, and as evidenced below, this shapes the issues and messages they are blogging about.

Between April 2016 and December 2020, Edstart published 81 blogs. All of these were downloaded for content analysis. As with other qualitative studies utilising blogs (cf. Alhojailan, 2012), thematic analysis was conducted to develop a set of themes. To do this, all blogs were carefully read and coded. These codes were then categorised into an initial set of 12 sub-themes. These sub-themes were then grouped together to generate four overarching themes: (1) Financial information blogs; (2) Parenting support blogs concerned with finances; (3) Parenting support blogs concerned with general issues; and (4) Other (see table 1). These themes, as well as a general overview of Edstart are discussed in the following sections.

\section{Case study: Edstart}

Edstart offers customised loan packages to 'simplify' the cost of paying school fees. Loans can cover all education-related expenses, including tuition, uniforms, technology items, textbooks and stationery, private tutoring, school trips and excursions, extra-curricular activities, and boarding expenses (Edstart, 2020). Edstart was founded in 2016 by Jack Stevens and Jonas Hallerby-both financial sector entrepreneurs-backed with $\$ 1$ million in seed funding from $\mathrm{H} 2$ Ventures ${ }^{2}$. While Edstart is predominately focussed on providing services to individual families, they are receiving growing interest from schools seeking to partner with them. On their website, for example, a specific section 'for schools' details how Edstart can help a school manage fee payments. As explained by the principal of Bishop Druitt College, in a case study video embedded on this page, Edstart has enabled them to offer financial support to families who are looking for flexible payment options; so while families can spread their payments over a year (or more), the school has access to funds immediately.

While Edstart's website suggests they are working with some of Australia's highest fee-paying schools, CEO Jack Stevens has been quoted as saying it is not the parents paying upwards of $\$ 30,000$ a year they are seeking to target. Rather, the "sweet spot" are those funding schooling at mid-tier schools where fees range from

\footnotetext{
${ }^{2} \mathrm{H} 2$ Ventures is a leading investor of fintech startup businesses in Australia and runs an annual accelerator programme, where 8-16 startups participate in a 6 month in-house pre-seed programme.
} 


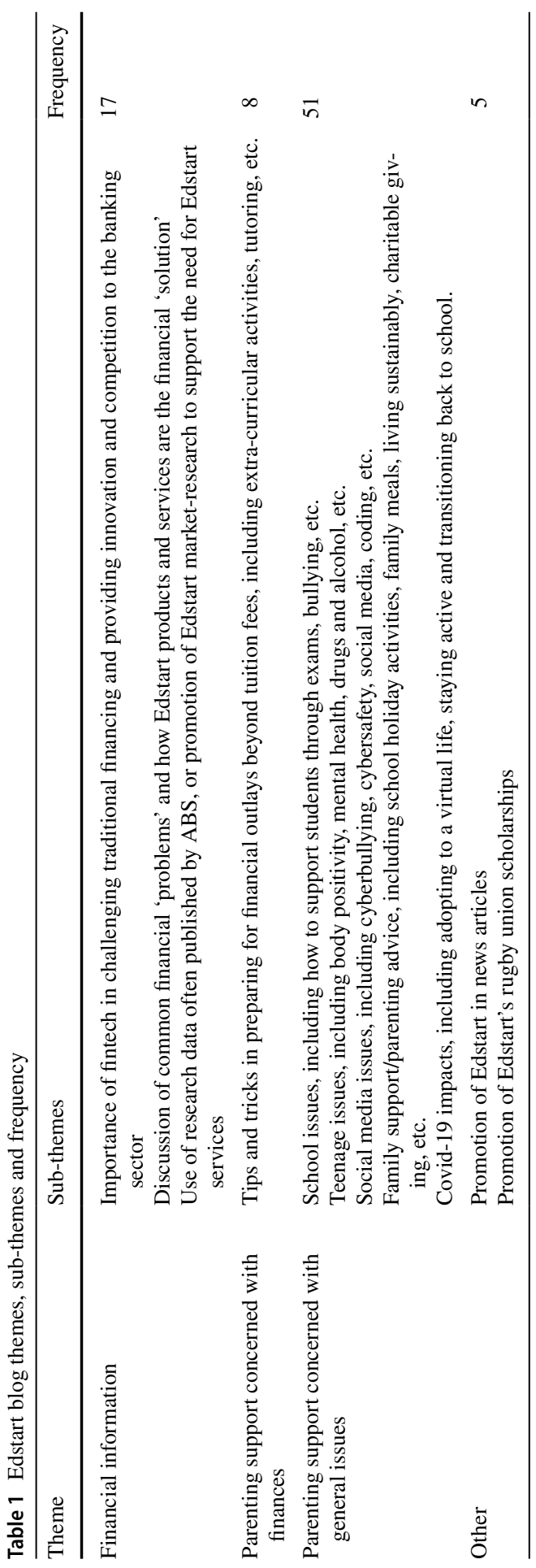


$\$ 8,000-\$ 20,000$ annually. "It's really about those families that are in an expensive phase in their lives, so they've still got mortgage repayments, maybe some investment properties, and then they've got two or three kids as well going to private school, which all stacks up" (Stevens quoted in Baldassarre, 2016). Stevens is quoted in a different article explaining, "there's an emotional commitment that parents have around education" and in some cases they are spending more on schooling than their mortgages (Bolton, 2019). The rationale for Edstart was to take this "pain point" away from families and that there was a clear gap in the market for a financing solution to support this. This same article by Bolton reports that Edstart has taken on $\$ 50$ million in fee management since 2017. Their largest customer is reported to have several children at boarding school with an annual cost of $\$ 160,000$ and their smallest loan is to a parent to cover $\$ 2000$ in government school costs (Bolton, 2019).

Edstart earns income from transaction fees on its loans, as well as interest on time-extended loans. There are two products available to parents. The first, 'Edstart Pay', is an interest-free loan to spread fee repayments over 12 months. Edstart pays school fees at the point they're due (whether this is each school term or by semester) and spreads repayments over weekly, fortnightly or monthly instalments. A 3\% transaction fee is charged for every invoice paid. Edstart Pay+ is offered by partner schools, where the transaction fee is taken care of by the school. The second product, 'Edstart Extend' allows parents to spread costs over a longer period (including any overdue fees), for up to five years beyond their last child finishing school. The interest rate attached to this loan varies from $5.9 \%$ to $12.9 \%$ depending on each applicant's credit profile. The same 3\% transaction fee per invoice also applies.

This model provides an attractive 'return versus risk' for investors. According to iPartners ${ }^{3}$, if you invest in Edstart-a 'Special Purpose Company' (SPC) - that holds a portfolio of loans, then the money you are lending to the SPC is used to make lots of smaller loans. As long as the SPC earns more money on its smaller loans then what it costs the SPC to pay the investor interest, then it has ongoing viability (iPartners, 2021). For example, iPartners has offered their investors two tranches to invest in Edstart. The first raised $\$ 1.95$ million and offered a $7 \%$ coupon (annual interest) on drawn capital (the loss protection on this meant that $35 \%$ of Edstart's underlying loans would have to default for investors to lose money) (iPartners, 2021). The second raised $\$ 1$ million where investors receive a $12 \%$ coupon. Obviously, the loss protection here was thinner, with only $5 \%$ of Edstart's underlying loans needing to default for investors to lose money (iPartners, 2021). However, as Bailey (2018, n.p.) notes, "that apparently thin line of defence does not seem so flimsy once you understand the behavioural economics behind parents paying for their children's education".

It is this point about understanding parents that is worth exploring further. Interestingly, the only other part of the Edstart website-other than an overview of its products, frequently asked questions and an application tool—is its blog. This blog

\footnotetext{
3 iPartners is an Australian venture capital firm that gives wholesale investors (with an individual investment of $\$ 10,000$ or more) direct access to a range of investments and asset classes.
} 
functions as the outward facing profile of Edstart. It is clearly written for a parent audience and has averaged more than one blog per month for the past four years. With so little information available on Edstart and its employees, this blog provides an interesting case for analysis.

\section{Financial information blogs}

Seventeen blogs published by Edstart fall within the theme of 'financial information' for parent consumers. These blogs work to define the need for Edstart in the Australian education market, and how their services are filling a gap in consumer demand by offering an innovative, fit-for-purpose product. For example, the first blog published in 2016 (prior to Edstart's public release) opens with an argument made by Stevens that there is a need for competition in the Australian banking industry, as traditional banks - particularly the 'Big 4'-are slow to develop new products and services. He argues that smaller innovative businesses will be able to bring better products to the market and deliver 'major benefits' to consumers. He calls for the government not to waste $\$ 50$ million on a Royal Banking Commission, but rather invest in Australia's rapidly growing fintech sector:

Young fintech companies are developing better, faster and cheaper ways to get things done in the finance world. If we want to make real and lasting change to the finance industry, the Australian fintech sector must be supported. It is the creative minds behind these young companies that will deliver major benefits to consumers. Large banks threatened with more regulation will not. $(16 / 04 / 2016)$

This first blog works to justify the need for an innovative fintech sector to provide competition for financial services. The rationale for this investment according to Stevens is not about profit making, but about working in the best interest of the consumer. Stevens positions fintechs as having the ability to "revolutionise" the banking and financial industry to "leave everyone better off".

A subsequent blog (28/06/2016) further argues how Edstart in particular is "helping families through one of the most expensive periods of their life". Stevens argues that Edstart is driven by the fundamental principle that "education is the world's most powerful investment" and that their "extensive research" has pointed to a significant problem for Australian families sending their children to high fee-paying schools. He argues that the financing needs of these families are varied, and that flexible, customised payment plans are required. Edstart, he observes, "is laying the first building block towards this vision... [and] when Edstart launches in July, families will finally have access to a better way to pay the remainder of their 2016 school fees and beyond".

Edstart appears to have a straightforward formula for communicating the need for their services to Australian families. A blog within the theme of finance starts with a financial 'problem'-often caused by the relics of a traditional banking system-citing key data to evidence this, and then proceeds to show how Edstart offers a financial 'solution'. For example, some blogs take issue with how families currently 
pay for school fees via the use of credit card debt (15/05/2016), investment bonds (15/07/2016), personal loans and extended family contributions (14/09/2018), and redrawing on their household mortgage (1/07/2019). These are often refuted as being financially risky. For instance, in the use of credit cards, Edstart warns that while this is fine if families pay off their card in time, many families end up carrying their school fee debt and pay significant interest on this. The solution is then provided:

Edstart is low cost. The underlying interest rates on our payment plans are less than half of the average credit card interest rate and cheaper than an unsecured personal loan or overdraft from a bank. There are no hidden fees, charges or early payment penalties. Never before has a service like this been offered for school fees. (15/05/2016)

Edstart also provides advice on how other issues might impact a family's ability to pay school fees. For example, one blog examines what changes to school fees parents might expect from the impact of Gonski reports. As explained in this post (15/05/2017),

Some would suggest that parents paying private school fees can simply absorb the impact of any fee increases which may be triggered by the school funding changes. Of course here at Edstart we know that for the vast majority of families that is simply not the case. We know that for most families:

- Private school fees are their number 1 or 2 largest family expense.

- $50 \%$ of families are currently spending more on school fees than they have in available disposable income.

This means that the ability of these parents to just "absorb" school fee increases is extremely limited.

This post finishes with a reassurance to readers that Edstart is available to help manage school fees and it is as simple as heading to their website to start calculating an appropriate Edstart package.

\section{Parenting support blogs}

\section{Finance advice}

The other category of blogs posted by Edstart seem to be focussed on providing general advice and information for parents. Although, there are two themes to these. The first are those that still have an underlying concern with finance. For example, the first blog of 2017, 'Top 6 tips to survive the first month back at school' is focussed on parents preparing for the financial outlay that happens beyond tuition fees, like school lunches, the cost of excursions and extra-curricular activities. Edstart recommends planning for these in advance so "these additional activities can be factored into your school budget" (12/02/2017). Similarly, a post on the 
importance of excursions and school trips (8/09/2019) reminds parents that "tuition fees are only the beginning when it comes to education-related expenses and why we've designed our payment plans to cover extras like excursions and extra-curricular activities". Another post examines the need for private tutoring (1/09/2019), also suggesting that Edstart can help parents cover these costs. There are other posts that seek to smooth over the financial complexities of sending children to different private schools as Edstart can manage fees across these (30/04/2017) and others that analyse how school fees are rising or falling in different states and in different school types, and how Edstart can help parents manage rising fees (21/09/2017; 10/10/2017; 10/03/2019; 26/03/2016).

\section{General parenting advice}

The second theme of posts does not reference any financial issue or concern. Instead, posts address issues that fall into 5 main sub-themes. First, are school issues. These include posts about how to help children prepare for exams, what to do after they have finished exams, how to know if your child is being bullied, or whether your child IS the bully. Second, are those focussed on teenage issues. These include how to decode teenage language (like Bae, Srsly, Frothing, On fleek, Slay, and the allimportant, PAW), how to motivate a teen to get a summer job, how to cope with raising a teenage boy, how to parent a teenage girl, body image positivity, how to 'govern respect' from teenagers, the dangerous teenage trends to be aware of, the conversation that needs to be had around the Netflix show'13 Reasons Why', how to spot signs of depression in teenagers, and how to discuss drugs and alcohol.

Third, are social media issues. These include how iGen is being impacted by their technology use, what TikTok is, the benefits of coding, what music choice says about a child's personality, the rise of cyberbullying, an awareness of cybersafety, how to educate children about fake news, and podcast recommendations. Fourth, are those post relating to family. For instance, posts focussed on advice for single parenting, how to keep the fun alive within a family, what to do as a family on school holidays, the benefits of cooking family meals, how to engage in charitable projects together, strategies for dealing with the death of a grandparent and how to live more sustainably as a family. Last were those posts related to Covid, including the need to adopt to a virtual life, how to tackle home improvement with kids, the importance of staying active, the transition back to 'normal', how to deal with children currently in Year 12 and what to expect from a Higher Education sector in turmoil.

In total, just over $60 \%$ of Edstart's blogs fall into this theme of general parenting advice. Like other research on corporate blogs (cf. Philip, 2017; Singh et al., 2008; Wei et al., 2020), this finding is not unexpected, and evidences Edstart's commitment to engage parent consumers through core business messaging and broad concerns and interests. General parenting advice-peppered with financial advice and the solutions that Edstart can provide, works to encourage parents to become regular consumers of the blog, and also speaks to Edstart's positioning of itself as a company committed to social enterprise, or the benefit they can bring to the consumer (rather than a focus on profit making). 


\section{Discussion and conclusion}

Edstart's new payment plans are being designed through a scalable technical platform. It is funded by venture capital, staffed and managed by entrepreneurs, and proposes a reimagining about which Australian families have the resources to afford school choice. The interweaving of venture capital, technical and financial expertise, and social enterprise is leading to the production of an edu-business that understands parent consumers - as evidenced by the Edstart blog-and provides a financial means for more parents to give their children access to a 'better' education.

The rise of edu-businesses is not a new phenomenon. But the advance of fintech edu-business is a novel development that deserves greater attention. Like Williamson (2018) argues of the edtech industry, we need to understand better both the specific market-making activities of emerging businesses, and also the effects of the new education markets they are creating. As the case of Edstart demonstrates, markets are made; and they are made in concrete contexts with specific conditions, and their realisation and maintenance include the creation of fitfor-purpose products. What has worked in Australia for Edstart, would not work in countries with low private school enrolments. However, this doesn't mean their product can't be scaled into different markets. Already, Edstart has identified their need in providing loans to students (who are over 18) to pay for their vocational or higher education. Also, $8 \%$ of Edstart's customer base are public school parents (Bolton, 2019). According to Bolton this was a surprising development for Edstart CEO Jack Stevens. However, recent research (Thompson et al., 2019; Rowe \& Perry, 2020) has pointed to the rising cost of all types of schooling in Australia, particularly within partially-/selective public schools that are often competing with private schools for enrolments. These public schools are charging fees up to $\$ 2,000$ per year and are thus comparable to lower-cost private schools. This indicates that financial strain is likely happening to parents across the income spectrum; regardless of the type of school they send their children to, or the cost of the associated school fees.

Edstart's focus on the needs of consumers mirrors other successful edu-business strategies. As Williamson (2020) argues, once a market need is identified, and a product created, a business needs to "frame and mediate the encounter between itself and its customers in multiple ways" (p.10). Edstart's website, their broad-scale marketing activities (e.g. radio, print and billboard advertising), and growing partnerships with schools allow it to build market relations. Their blog in particular-which is posted across an array of social media platforms-is a pragmatic intermediary device that works to enable market encounters by directing readers to Edstart's website and products. The financialisation of school choice through the escalation of personal debt for consumers represents a mutually beneficial relation between consumer reform and profit. Edstart's business strategy asserts a moral and financial complementarity where 'doing well is done by doing good'. Edstart is contributing to a reimagining of the education market through the production of an infrastructure in which market exchanges become a sensible 
and necessary form for the consumption of education (Ball, 2019). As Ball (2019, p. 44) observes, 'this infrastructure is layered and complex, is constantly evolving, and is made up of multi-faceted partnerships, collaborations, and exchanges. There are financial, discursive, and arguably social 'returns' achieved here, a commodifying and marketing effect, making education ever more business and market 'ready'. This, at least in Australia, has been necessitated by the value placed in education as a private, positional good (Verger et al., 2016).

It seems likely that Edstart-as a fintech newcomer-will continue to grow and expand. The long-term effect of these 'boutique' or customised financial solutions within the broader market of traditional banking services, at least in the Australian school context, is yet to be seen. Indeed, the analysis within this paper is necessarily limited due to the lack of publicly available information on Edstart (e.g. annual reports, profit analyses, investment strategies, and so on). Future research needs to expand on this exploratory analysis to investigate the global emergence of fintech edu-businesses, including how they operate, who they serve, and the affordances and (perhaps unintended) consequences of their activities for normalising education privatisation. While my concluding thoughts might be speculative, it certainly seems plausible that Edstart is providing a service that benefits from, and ascribes further value to, the logics of choice within Australian schooling.

Edstart has established an infrastructure that contributes to the financialisation of choice, potentially shifting how school access is represented and understood. Rather than simply accepting the 'basic education' offered by state governments, Edstart presents parents with an enhanced opportunity to engage in low-risk lending to expand their access to a school of choice. As others have warned, Australia's school system is stratifying on the basis of wealth (Rowe \& Perry, 2020), and the services offered by Edstart work to cement popular discourse that free or low-cost public schooling is as a social safety net for those who cannot afford an alternative (Gerrard et al., 2017). Remember, the 'sweet spot' or biggest clientele for Edstart according to CEO, Jack Stevens, are Australia's middle-income earners - those that are aspirational about school choice, but often don't have access to an easy financial 'solution' to the 'problem' of high school fees. The concern here is that Edstart, and increasing levels of private debt, are normalising the payment of school fees and in so doing, contributing to the rollback of the welfare state and the responsibility of governments to fund a robust education system.

Funding This work was supported by the Australian Research Council [DE210100994].

Declarations

Conflict of interest No potential conflict of interest.

\section{References}

ABS (2020). Schools. Retrieved from: https://www.abs.gov.au/statistics/people/education/schools/2019 
Alhojailan, M. I. (2012). Thematic analysis: A critical review of its process and evaluation. West East Journal of Social Sciences, 1(1), 39-47.

Australian Scholarships Group. (2016). The cost of educating a child in Australia. https://www.asg.com. $\mathrm{au} /$ doc/default-source/Media-Releases/Planning-for-Education-Index-2016/ASG_PLANNING_ FOR_EDUCATION_INDEX_NATIONAL_MEDIA_RELEASE_FINAL_WEB.pdf

Bailey, M. (2018). iPartners first to securitise private school loans in oversubscribed offer. Financial Review. https://www.afr.com/policy/health-and-education/ipartners-first-to-securitise-privateschool-loans-in-oversubscribed-offer-20180413-h0yq0a

Baldassarre, G. (2016). Sydney fintech startup Edstart provides parents with a financing solution for education costs. Startupdaily. https://www.startupdaily.net/2016/08/sydney-fintech-startup-edstart-provi des-parents-financing-solution-education-costs/

Ball, S. J. (2012). Global education inc: New policy networks and the neo-liberal imaginary. Routledge.

Ball, S. J. (2019). Serial entrepreneurs, angel investors, and capex light edu-business start-ups in India: Philanthropy, impact investing, and systemic educational change. In Gita Steiner-Khamsi \& Christiane Thompson (Eds.), Marcelo Parreira do Amaral (pp. 23-46). Cham: Researching the global education Industry. Palgrave Macmillan.

Bollaert, H., de Silanes, F. L., \& Schwienbacher, A. (2021). Fintech and access to finance. Journal of Corporate Finance. https://doi.org/10.1016/j.jcorpfin.2021.101941

Bolton, R. (2019). Venture capital sees window in education. Financial Review. https://www.afr.com/ work-and-careers/education/venture-capital-sees-window-in-education-20191122-p53d26

Bonnor, C., \& Shepherd, B. (2016). Uneven playing field: The state of Australia's schools. Centre for Policy development.

Brown, E., \& Piroska, D. (2021). Governing fintech and fintech as governance: The regulatory sandbox, riskwashing, and disruptive social classification. New Political Economy. https://doi.org/10.1080/ 13563467.2021.1910645

Cooper, M. (2017). Family values: Between neoliberalism and the new social conservatism. MIT Press.

Cooper, M. (2020). Neoliberalism's Family Values: Welfare, Human Capital, and Kinship. In P. Mirowski, D. Plehwe\& Q. Slobodian (Eds.), Nine Lives of Neoliberalism (pp. 95-119). London: Verso.

Di Bartolo, L. (2005). Educational polarisation in Brisbane: Rawls's least advantaged and the myth of choice. Australian Educational Researcher, 32(3), 63-82.

English, R. (2009). Selling education through "culture": Responses to the market by new, non-government schools. The Australian Educational Researcher, 36(1), 89-104.

Fitzgerald, S., Stacey, M., McGrath-Champ, S., Parding, K., \& Rainnie, A. (2018). Devolution, market dynamics and the Independent Public School initiative in Western Australia: 'winning back' what has been lost?. Journal of education policy, 33(5), 662-681.

Forsey, M., Proctor, H., \& Stacey, M. (2017). A most poisonous debate: Legitimizing support for Australian private schools. In Thomas Koinzer, Rita Nikolai, \& Florian Waldow (Eds.), Private schools and school choice in compulsory education (pp. 49-66). Wiesbaden: Springer VS.

Gabor, D., \& Brooks, S. (2017). The digital revolution in financial inclusion: international development in the fintech era. New Political Economy, 22(4), 423-436.

Gerrard, J., Savage, G. C., \& O'Connor, K. (2017). Searching for the public: School funding and shifting meanings of 'the public' in Australian education. Journal of Education Policy, 32(4), 503-519.

Gonski, D., Boston, K., Greiner, K., Lawrence, C., Scales, B. \& Tannock, P. (2011). Review of funding for schooling. Department of Education, Employment and Workplace Relations (Australia).

He, W., \& Chen, Y. (2014). Using blog mining as an analytical method to study the use of social media by small businesses. Journal of Information Technology Case and Application Research, 16(2), 91-104.

HerckGiaquinto, L., \& Bortoluzzo, A. B. (2020). Angel investors, seed-stage investors and founders influence on FinTech funding: An emerging market context. Macroeconomics and Finance in Emerging Market Economies, 13(3), 276-294.

Ho, C. (2019). Angry Anglos and aspirational Asians: Everyday multiculturalism in the selective school system in Sydney. Discourse: studies in the cultural politics of education, 40(4), 514-529.

Hogan, A., Sellar, S., \& Lingard, B. (2016). Commercialising comparison: Pearson puts the TLC in soft capitalism. Journal of Education Policy, 31(3), 243-258.

iPartners. (2021). Edstart secured loan. https://ipartners.iplatforms.com.au/deal/info/edstart_junior_secur ed_loan_series_2_-_tranche_B?tab=deal-generalpage 
ISA (2017). Parents and school choice. Retrieved from: https://isa.edu.au/about-independent-schools/ about-independent-schools/parents-and-school-choice/

Kenway, J. (2013). Challenging inequality in Australian schools: Gonski and beyond. Discourse: Studies in the cultural politics of education, 34(2), 286-308.

Lai, K. (2017). Financialisation of everyday life. In G. Clark, M. Feldmann, M. Gertler \& D. Wojcik (Eds.), The New Oxford Handbook of Economic Geography (pp. 611-627). New York: Oxford University Press.

Laws, T. A., \& Fiedler, B. (2002). Calculating the true cost of private school education: based on a survey of South Australian School fees. Australian Journal of Social Issues, 37(4), 447-459.

Le Grand, J. (2009). The other invisible hand: Delivering public services through choice and competition. Princeton University Press.

Lingard, B. (2000). Federalism in schooling since the Karmel Report (1973), Schools in Australia: from modernist hope to postmodernist performativity. Australian Educational Researcher, 27(2), 25.

Martin, R., Rafferty, M., \& Bryan, D. (2008). Financialization, risk and labour. Competition \& Change, 12(2), 120-132.

Philip, L. (2017). Corporate blogging: The new age PR tool. European Journal of Interdisciplinary Studies, 3(3), 65-75.

Potts, A. (1997). Public and private schooling in Australia-Historical and contemporary considerations. Institute of Historical Research Retrieved.

Rowe, E., \& Perry, L. B. (2020). Inequalities in the private funding of public schools: parent financial contributions and school socioeconomic status. Journal of Educational Administration and History, 52(1), 42-59.

Singh, T., Veron-Jackson, L., \& Cullinane, J. (2008). Blogging: A new play in your marketing game plan. Business Horizons, 51(4), 281-292.

Soriano, M. (2018). How fintech startups succeed in financial inclusion. Asian Management Insights, $5(1), 58-63$.

Thompson, G., Hogan, A., \& Rahimi, M. (2019). Private funding in Australian public schools: a problem of equity. The Australian Educational Researcher, 46(5), 893-910.

Thompson, G., Savage, G., \& Lingard, R. (2016). Introduction: Think tanks, edu-businesses and education policy: Issues of evidence, expertise and influence. Australian Educational Researcher, 43(1), $1-13$.

Verger, A., Lubienski, C., \& Steiner-Khamsi, G. (Eds.). (2016). World yearbook of education 2016: The global education industry. Routledge.

Vickers, M. (2005). In the common good: The need for a new approach to funding Australia's schools. Australian Journal of Education, 49(3), 264-277.

Wade, M. \& Singhal, P. (2018). Private schools, costly private gain. The Sydney Morning Herald. https:// www.smh.com.au/national/nsw/private-schools-costly-private-pain-20180126-h0ouy8.html

Wei, Y., McIntyre, F. S., \& Straub, D. (2020). Does micro-blogging lead to a more positive attitude toward a brand?-A perspective of cultivation theory. Journal of Promotion Management, 26(4), 504-523.

Weichert, M. (2017). The future of payments: How FinTech players are accelerating customer-driven innovation in financial services. Journal of Payments Strategy \& Systems, 11(1), 23-33.

Williamson, B. (2018). Silicon startup schools: technocracy, algorithmic imaginaries and venture philanthropy in corporate education reform. Critical Studies in Education, 59(2), 218-236.

Williamson, B. (2020). Making markets through digital platforms: Pearson, edu-business, and the (e)valuation of higher education. Critical Studies in Education. https://doi.org/10.1080/17508487.2020. 1737556

Winton, S., \& Milani, M. (2017). Policy advocacy, inequity, and school fees and fundraising in Ontario, Canada. Education Policy Analysis Archives, 25(40), 1-29.

Publisher's Note Springer Nature remains neutral with regard to jurisdictional claims in published maps and institutional affiliations.

Anna Hogan is a senior research fellow in the School of Teacher Education and Leadership at the Queensland University of Technology. 